\title{
DNA Synthesis in Gamma-irradiated Recombination Deficient [Strains of Escherichia coli
}

\author{
By W. J. H. GRAY, M. H. L. GREEN AND B. A. BRIDGES \\ MRC Cell Mutation Unit, University of Sussex, Falmer, Brighton, Sussex \\ (Accepted for publication 8 February 1972)
}

\begin{abstract}
SUMMARY
DNA synthesis in $\operatorname{rec} A$ and $\operatorname{rec} A \operatorname{exr} A$ strains of Escherichia coli is strongly inhibited without delay by low doses of gamma-radiation. The synthesis that does occur in these strains appears to take place mainly on chromosomes that have not received a lethal hit. Low doses produce much less inhibition of DNA synthesis in $\operatorname{exr} A, \operatorname{rec} B, \operatorname{rec} A \operatorname{rec} B$ and wild-type strains. We conclude that the $\operatorname{rec} A^{+}$gene product acts immediately, certainly before DNA replication, in the repair of lesions produced by gamma-irradiation. In $\operatorname{rec} B$ bacteria the $\operatorname{rec} A^{+}$gene product is not required for continued DNA synthesis, although the synthesis which occurs in rec $A$ rec $B$ strains may be abnormal since it is not reflected in increased survival. The exr $A^{+}$gene product is not necessary for continued DNA replication, suggesting that its time of action in repair may be at a later stage.
\end{abstract}

\section{INTRODUCTION}

The most easily observed effect of gamma-irradiation on bacterial DNA is the introduction of single strand breaks. One class of breaks is transient, repair occurring rapidly by a process requiring Kornberg polymerase (Town, Smith \& Kaplan, 197I) whereas another rarer class undergoes repair slowly by a process requiring the $\operatorname{rec} A^{+}, \operatorname{rec} B^{+}$and $\operatorname{exr} A^{+}$gene products (McGrath \& Williams, 1966; Morimyo, Horii \& Suzuki, 1968; Kapp \& Smith, 1970). Although it is not known whether this slow repair process occurs before, during or after DNA replication, its slowness suggests that gaps could persist until replication. Moreover, the effects of gamma-irradiation on conjugation (Green, Bridges \& Riazuddin, I97I) suggest that $\mathrm{rec} \mathrm{A}^{+}$-dependent repair is completed during or after replication of DNA bearing the lesion. Cairns \& Davern (1966), however, have found that one ${ }^{32} \mathrm{P}$-induced double strand break anywhere in the chromosome is sufficient to inhibit DNA synthesis immediately in a presumed $\operatorname{rec} A$ strain and this result would imply that $r e c A^{+}$-dependent repair of ${ }^{32} \mathrm{P}$ damage must occur before DNA replication can continue.

In an attempt to clarify the situation we have examined DNA synthesis immediately after gamma-irradiation in $\operatorname{rec} A, \operatorname{rec} B, \operatorname{rec} A \operatorname{rec} B, \operatorname{exr} A$ and $\operatorname{rec} A$ exr $A$ strains of Escherichia coli. Our results clearly separate the $\operatorname{rec} A^{+}, \operatorname{rec} B^{+}$and $\operatorname{exr} A^{+}$functions.

\section{METHODS}

Bacterial strains. Escherichia coli $\mathrm{K}-\mathrm{I} 2 \mathrm{ABI}$ I 57 (u.v.-resistant) and its derivatives AB2463 recA13, AB2470 recB2I (Howard-Flanders \& Boyce, I966), JC5495 recAI3 recB2I (Willets \& Clark, I969), PAM57I 7 exr $A$ (Donch, Green \& Greenberg, I968) and CM293 recA56 exr $A$ were used. 
The strain CM293 recA exrA was a $h i s^{+}$recombinant selected from a mating between strain JC5088 Hfr rec $A 56$ and strain PAM57I 7 exr $A$. In this cross exr $A^{+}$is transferred as an extreme distal marker and mating was interrupted at $20 \mathrm{~min}$ before the $\operatorname{exr} A^{+}$gene could be transferred. The recombinant was classified as $\operatorname{rec} A$ on the basis of its greater u.v. sensitivity and altered DNA synthesis after gamma-irradiation. It was presumed exr $A$ because mating had been interrupted, because it retained the auxotrophic markers of PAM57I7, and because it retained the robust growth of PAM57I7 rather than the slower growth of a $\operatorname{rec} A$ strain.

We are indebted to Dr A. J. Clark and Dr P. Howard-Flanders for the other strains used.

Cultural conditions. Cultures were grown at $37^{\circ} \mathrm{C}$ with shaking in $\mathrm{M} 9$ minimal medium supplemented with $0.4 \%(\mathrm{w} / \mathrm{v})$ glucose and $\mathrm{I} \%$ (w/v) Difco Casamino acids. Overnight stationary cultures were diluted into fresh medium (I/I00 ABII57, PAM57I7, CM293; $\mathrm{I} / 50 \mathrm{AB} 2463 ; \mathrm{I} / 25 \mathrm{AB} 2470, \mathrm{JC} 5495$ ) and grown for $3 \mathrm{~h}$.

Irradiation. Samples of $3 \mathrm{~h}$ cultures were irradiated at room temperature with aeration in a ${ }^{60} \mathrm{Co}$ 'hot-spot' source at a dose rate of $4.5 \mathrm{krad} / \mathrm{min}$. Viability of irradiated samples was determined on plates of Oxoid Nutrient Broth no. 2 solidified with $\mathrm{I} \cdot 5 \%$ Davis New Zealand Agar.

Radiochemicals. [ ${ }^{3} \mathrm{H}$-methyl]thymidine (specific radioactivity $26 \mathrm{Ci} / \mathrm{mm}$ ), $\left[2-{ }^{14} \mathrm{C}\right]$ uracil $(60 \mathrm{mCi} / \mathrm{mm}),\left[{ }^{\left[{ }^{14}\right.} \mathrm{C}\right]$ adenine $(60 \mathrm{mCi} / \mathrm{mm}),\left[{ }^{-14} \mathrm{C}\right]$ guanine $(55 \mathrm{mCi} / \mathrm{mm}),\left[2-{ }^{14} \mathrm{C}\right]$ thymidine $(60 \mathrm{mCi} / \mathrm{mm})$, and $\left[{ }^{3} \mathrm{H}\right.$-methyl]thymidylic acid ( $12 \mathrm{Ci} / \mathrm{mm}$ ) were obtained from The Radiochemical Centre, Amersham, Buckinghamshire.

\section{Measurement of DNA synthesis}

(a) Incorporation of $\left[{ }^{3} \mathrm{H}\right]$ thymidine. Immediately after irradiation, $3 \mathrm{ml}$ of each sample was added to $7 \mathrm{ml}$ of warmed fresh medium containing Io $\mu \mathrm{Ci}\left[{ }^{3} \mathrm{H}\right.$-methyl]thymidine. At $\mathrm{I}$, $2,3,4,5,6,8$ and to min, I ml samples were pipetted into $4 \mathrm{ml}$ ice-cold $10 \%(\mathrm{w} / \mathrm{v})$ trichloroacetic acid. The acid insoluble fraction was collected and assayed for radioactivity as described previously (Green, Gray, Murden \& Bridges, I97I).

(b) Incorporation of other precursors. Measurements of the rate of uptake of radioactivity into DNA from labelled adenine, guanine and uracil were performed in the presence of $100 \mu \mathrm{g} / \mathrm{ml}$ rifampicin, in order to prevent incorporation into RNA (Wehrli, Knusel, Schmid \& Staehelin, 1968). The antibiotic was added as a concentrated methanolic solution 5 min before irradiation. After irradiation the cultures were rewarmed to $37^{\circ} \mathrm{C}$ and the samples were added to the labelled precursor to give a final concentration of $0 \cdot 25 \mu \mathrm{Ci} / \mathrm{ml}$. Samples of I $\mathrm{ml}$ were removed at intervals and added to $2 \mathrm{ml} \mathrm{I} \mathrm{N-KOH}$ and incubated at $37^{\circ} \mathrm{C}$ for $\mathrm{I} 8 \mathrm{~h}$ in order to hydrolyse any residual labelled RNA (Gray \& Midgley, I971). The labelled DNA was precipitated with an excess of ice-cold Io \% (w/v) trichloroacetic acid and assayed for radioactivity as before.

Rifampicin was a kind gift from Lepetit Pharmaceuticals Ltd, Maidenhead, Berkshire.

Measurement of DNA breakdown. Breakdown of DNA was estimated by observing the loss of trichloroacetic acid precipitable radioactivity from labelled cells. Cultures were labelled for Io min with $\mathrm{I} \mu \mathrm{Ci} / \mathrm{ml}\left[{ }^{3} \mathrm{H}\right.$-methyl]thymidine, filtered on Millipore filters $(0.45 \mu$ pore size), washed on the filter with an equal volume of distilled water, resuspended in fresh medium and incubated for Io min to allow self-chasing to occur. Almost identical results were obtained when cultures were randomly labelled with $\left[{ }^{3} \mathrm{H}\right.$-methyl]thymidylic acid (Breitman, Bradford \& Cannon, I967). 


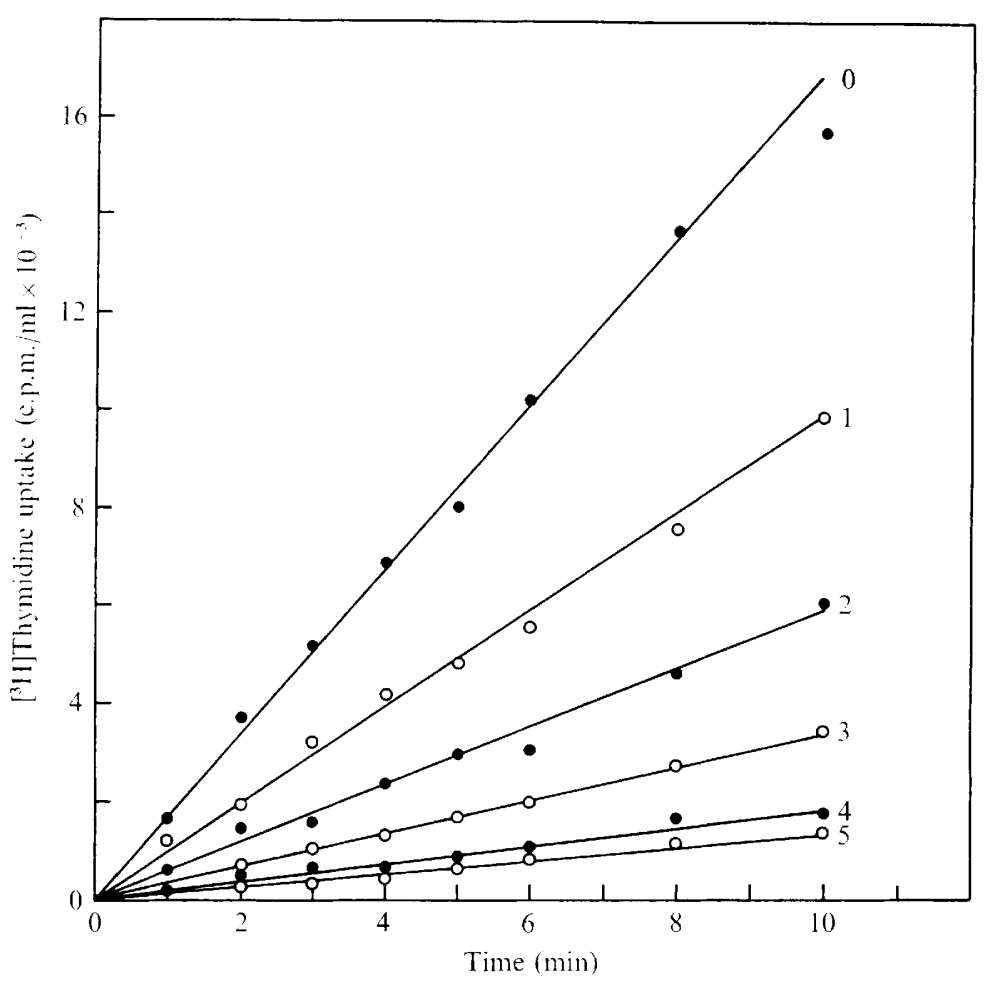

Fig. 1 . Effect of various doses of aerobic $\gamma$-irradiation (o to $5 \mathrm{krads}$ ) on the uptake of [ $\left.{ }^{3} \mathrm{H}\right]$ thymidine into the cold acid insoluble fraction of $\mathrm{AB} 2463$.

\section{RESULTS}

The rate of DNA synthesis immediately after irradiation was estimated by observing the rate of incorporation of tritiated thymidine into the cold acid insoluble fraction. Over the ro min period, uptake was found to be linear in all cases (Fig. I). Values for the rate of uptake of thymidine were obtained by applying linear regression analysis to the results. Rates of uptake, expressed as a percentage of that in an unirradiated sample, are presented in subsequent figures as a function of radiation dose.

Compared with the wild-type, DNA synthesis in the recA strain was extremely sensitive to gamma radiation, the kinetics suggesting immediate inhibition by a single hit (strand break?) with a target size about the same as that for lethality (Fig. $2 a, b$ ). If the same lesion both kills and immediately stops DNA synthesis in the recA strain, the residual synthesis observed should be almost entirely on chromosomes escaping such a lesion. An experiment supporting this conclusion is described below.

The $\operatorname{rec} B$ strain did not show the high sensitivity of the recA strain and at higher doses DNA synthesis was somewhat more resistant than in the wild-type. It is significant that the high sensitivity of the rec $A$ strain to immediate inhibition requires the $\operatorname{rec} B^{+}$gene product since DNA synthesis in the recA recB strain was as resistant as that in the recB strain.

In contrast to the recA strain, immediate post-irradiation DNA synthesis in the exrA strain was almost as resistant to radiation as in the wild-type strain (Fig. $3 a$ ). The recA exrA double mutant, unlike the $\operatorname{rec} A \operatorname{rec} B$, showed a high sensitivity similar to that of the $\operatorname{rec} A$ 

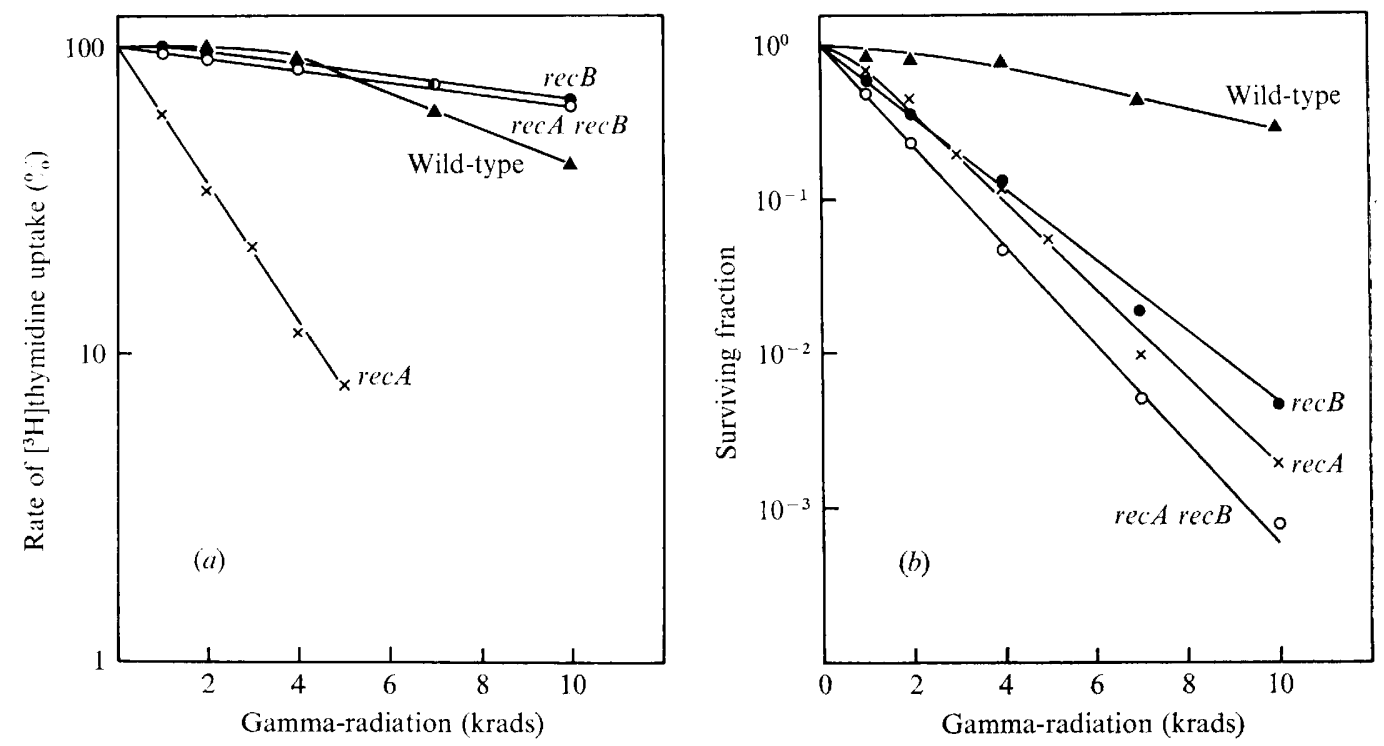

Fig. 2. (a) Effect of aerobic $\gamma$-irradiation on the rate of uptake of $\left[{ }^{3} \mathrm{H}\right]$ thymidine into cold acid insoluble material of strains $\mathrm{ABI} I 57$ wild-type, $\mathrm{AB} 2463 \mathrm{rec} A, \mathrm{AB} 2470 \mathrm{rec} B$ and JC5495 rec $A \mathrm{rec} B$; the rate is expressed as a percentage of the rate of uptake into an unirradiated control culture. $(b)$ Effect of aerobic $\gamma$-irradiation on survival of the same strains.
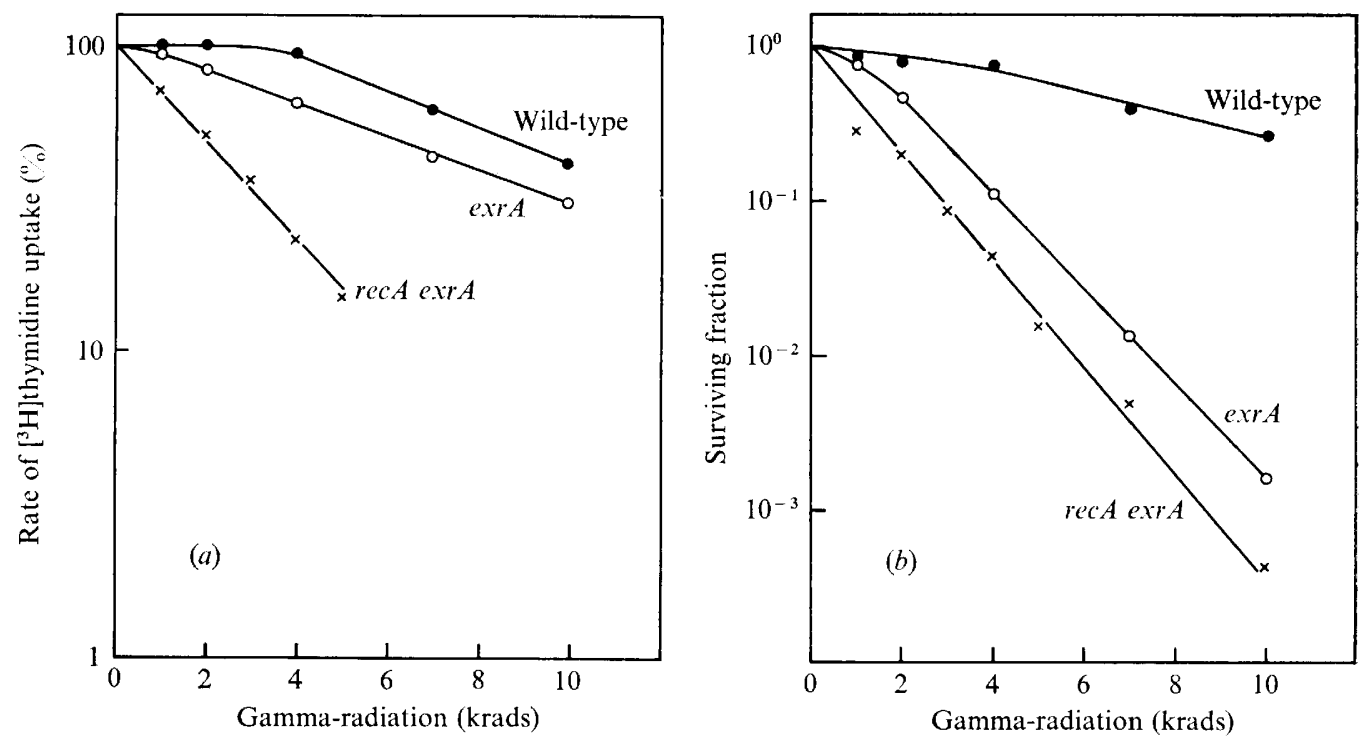

Fig. 3. (a) Effect of aerobic $\gamma$-irradiation on the rate of uptake of $\left[{ }^{3} \mathrm{H}\right]$ thymidine into cold acid insoluble material of strains ABI 157 wild-type, PAM57I7 exrA and CM293 recA exrA; the rate is expressed as a percentage of the rate of uptake into an unirradiated control culture. (b) Effect of aerobic $\gamma$-irradiation on survival of the same strains. 
Table I. Rate of DNA synthesis after gamma-irradiation as measured by uptake of different bases

Strain AB2463 rec $A$ received o or 2 krads gamma-irradiation and was incubated with the different bases for 40 min as described in Methods.

The results for $\left[{ }^{3} \mathrm{H}\right]$ thymidine incorporation over a Io $\mathrm{min}$ period, which were used to calculate Fig. $2 a$, are included for comparison.

Rate of DNA synthesis after 2 krads relative to unirradiated control $(\%)$ Experiment no.

$\left[{ }^{3} \mathrm{H}\right]$ Thymidine over $10 \mathrm{~min}$ $\left[{ }^{14} \mathrm{C}\right]$ Thymidine over $40 \mathrm{~min}$

$\left[{ }^{14} \mathrm{C}\right]$ Adenine

$\left[{ }^{14} \mathrm{C}\right]$ Guanine

$\left.{ }^{[14} \mathrm{C}\right]$ Uracil

([14 C]Uridine was used in one experiment)

2

$30 \cdot 8$

$29 \cdot 3$

28.9

$35^{\circ} \mathrm{O}$

$35^{\circ} \mathrm{O}$

3
$35 \cdot 7$
$21 \cdot 0$
$24 \cdot 0$
$33 \cdot 5$
$34 \cdot 2$

4
$37 \cdot 0$
-
-
-

Mean

$34 \cdot 6$

$26 \cdot 2$

$28 \cdot 3$

33.7

$35 \cdot 7$

strain. Despite the different sensitivities of immediate post-irradiation DNA synthesis, all the Rec and Exr strains were about four times more sensitive than the wild-type to the lethal action of gamma radiation (Fig. $2 b, 3 b$ ). Thus, in these strains post-irradiation DNA synthesis is not correlated with survival in any simple way.

A number of other strains bearing comparable mutations has also been tested and found to behave similarly to those for which detailed data have been given; they include NG30 rec $\mathrm{A}$ and JC5088 rec $A$ (which resembled AB2463 recA), JC5489 recC (which resembled AB2470 recB), and AB2494 lex (which resembled PAM57I 7 exrA). Our results are therefore likely to be attributable to the mutations studied rather than to any unsuspected strain differences. We noticed, however, that DNA synthesis in these strains after gamma-irradiation was almost the reciprocal of DNA breakdown (W. J. H. Gray, M. H. L. Green \& B. A. Bridges, unpublished observations). It was thus possible that the apparent inhibition of DNA synthesis which we observed might have been due to incorporation of (cold) breakdown products in preference to exogenous $\left[{ }^{3} \mathrm{H}\right]$ thymidine. We therefore examined the uptake of ${ }^{14} \mathrm{C}$-labelled uracil, adenine, guanine and thymidine into DNA, as described in Methods. Uracil is incorporated into DNA as both thymine and cytosine, and for both of these bases the competition with breakdown products should be different from that for exogenous thymidine. A similar argument also applies to adenine and guanine, since their pool sizes differ (Buchwald \& Britten, 1963). Nevertheless we obtained results for incorporation of these bases into strain $\mathrm{AB} 2463 \mathrm{rec} A$ after gamma-irradiation which were substantially similar to those observed for $\left[{ }^{3} \mathrm{H}\right]$ thymidine incorporation (Table I).

Moreover, Green, Bridges \& Riazuddin (I97I) have shown that under conditions where normal DNA synthesis is totally inhibited by gamma-irradiation in recA male and female strains, conjugation DNA synthesis may still be detected. This implies that if DNA synthesis were occurring in gamma-irradiated $r e c A$ strains it would be detected.

Further evidence suggesting that the inhibition of DNA synthesis which we observed was genuine came from a comparison of the stability of DNA synthesized after irradiation with that of existing DNA. It can be seen from Fig. 4 that in a recA culture the stability of DNA synthesized after irradiation ( 2 krads) corresponds more closely to the stability of DNA in unirradiated cells, than to the stability of existing DNA in an irradiated culture. Moreover, after a second dose, this post-irradiation DNA breaks down to almost exactly the same extent 


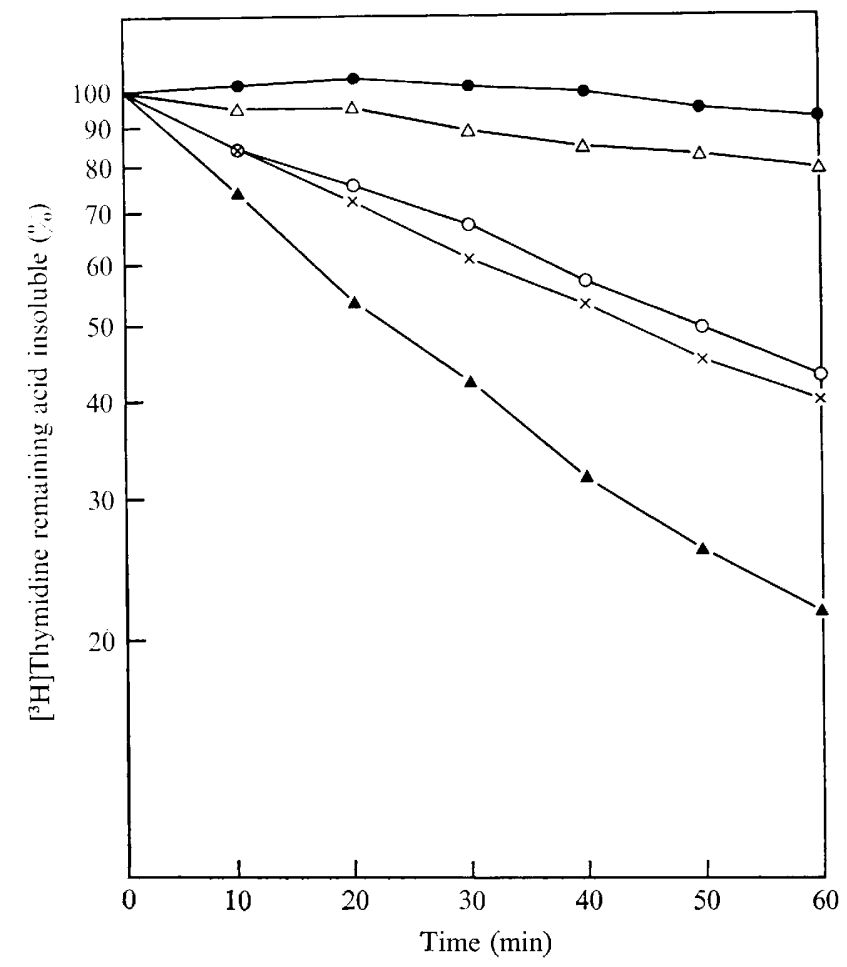

Fig. 4. The stability of DNA synthesized after fractionated doses of $\gamma$-radiation in $\operatorname{strain}^{-}$AB2 $263^{-1}$ recA. Cultures were labelled for $10 \mathrm{~min}$ as described in Methods, the label was removed and the cultures allowed to self-chase for $10 \mathrm{~min}$. Cultures were irradiated immediately before or $10 \mathrm{~min}$ after labelling. Loss of acid insoluble radioactivity was measured from Io min after label was removed. - Culture receiving no irradiation; $O$, culture receiving $2 \mathrm{krad}$ after labelling; $\boldsymbol{\Lambda}$, culture receiving $4 \mathrm{krad}$ after labelling; $\triangle$, culture receiving $2 \mathrm{krad}$ before labelling; $\times$, culture receiving 2 'krad before labelling and a further $2 \mathrm{krad}$ after labelling.

as existing DNA which has received a single dose. Thus, the DNA synthesized after irradiation in a recA strain behaves as if it has largely been synthesized on the undamaged fraction of chromosomes in the population.

It is also clear from this experiment that the apparent rate of DNA synthesis is not greatly reduced by recycling of DNA breakdown products. If we consider the fate of the existing DNA, at least $55 \%$ is broken down and released into the medium after irradiation (Fig. 4) and about $45 \%$ remains stable. Most of this $45 \%$ is required to act as template for the stable DNA synthesized after irradiation. Following 2 krads irradiation, 34.6\% as much exogenously labelled DNA is synthesized as in the unirradiated culture (Fig. 2a). Of this DNA $79.6 \%$ is stable (Fig. 4), which implies that $27.5 \%(34.6 \times 79.6 / 100)$ of the existing DNA is needed to act as stable template for the new stable exogenously labelled DNA. Thus $8 \cdot 7 \%$ $-(45-27 \cdot 5) / 2$ - of the existing DNA is recycled into stable DNA and $8 \cdot 7 \%$ of the existing DNA must act as a stable template for this recycled DNA. From several experiments of this type we calculate that not more than 5 to $10 \%$ of the existing DNA is recycled. A similar figure was obtained for the DNA synthesis resistant strain exrA.

We may therefore be slightly underestimating the rate of DNA synthesis after irradiation. However, the relative levels observed remain unchanged. 


\section{DISCUSSION}

The rec $A^{+}$-dependent repair of single strand DNA breaks produced by ionizing radiation is known to be a slow process requiring the equivalent of approximately one replication time for completion (McGrath \& Williams, I966; Smith, I97I). The high radiation sensitivity of the initial rate of DNA synthesis that we have observed in the $\operatorname{rec} A$ and $\operatorname{rec} A$ exr $A$ strains implies an immediate requirement for the $r e c A^{+}$gene product if DNA replication is to continue. This requirement appears to be waived in the absence of the $\mathrm{rec} \mathrm{B}^{+}$gene product, although the resulting synthesis may be abnormal as repair of single strand breaks certainly does not occur (Smith, I97I). Since the $\mathrm{rec}^{+}$gene product is also necessary for radiationinduced DNA breakdown in recA strains (Kapp \& Smith, 1970), inhibition of synthesis and breakdown may be causally related one to another.

The time of action of the $\operatorname{rec}^{+}$gene product is problematical. Although the $r e c B^{+}$gene product is involved in immediate inhibition of DNA synthesis after irradiation of a recA strain, this could be a pathological condition and does not necessarily imply early action during repair in a $\operatorname{rec} A^{+}$strain. The $\operatorname{exr} A^{+}$gene product appears not to affect post-irradiation DNA synthesis and may be involved in some subsequent stage of repair.

A hypothesis consistent with our results is that repair of ionizing radiation damage occurs in at least two steps widely separated in time; an immediate action of the $\operatorname{rec} \mathrm{A}^{+}$gene product followed some time later by the action of the $\operatorname{exr} A^{+}$gene product (quite possibly at or after the time of replication of the damaged region). If continued DNA synthesis is necessary for repair to occur it is conceivable that the $\operatorname{rec} A$ strain is sensitive because it cannot continue to synthesize on a damaged chromosome rather than because the $\operatorname{rec} A^{+}$gene product has any direct role in the actual repair steps. We can not, of course, discount the possibility that any of these gene products (including the $\mathrm{recA^{+ }}$ ) have more than one point of action in the repair sequence. Our results are essentially in agreement with those of Cairns and Davern (1966) for ${ }^{32} \mathrm{P}$ decay, implying an immediate interaction between a lesion and a replication point remote from it. However, their hypothesis that strand breaks might inhibit DNA synthesis by interrupting a driving torque mechanism requires modification. One would have to postulate that only gaps enlarged by uncontrolled $\operatorname{rec} B$ nuclease activity are effective in inhibiting DNA synthesis.

We should like to thank Miss Anne Rothwell and Mr D. J. Murden for their expert technical assistance.

\section{REFERENCES}

Breitman, T. R., Bradford, R. M. \& Cannon, W. D. (1967). Use of exogenous deoxythymidylic acid to label the deoxyribonucleic acid of growing wild-type Escherichia coli. Journal of Bacteriology 93 , 147 II 472 .

Buchwald, M. \& BRITten, R. J. (1963). Incorporation of ribonucleic acid bases into the metabolic pool and RNA of E. coli. Biophysical Journal 3, I55-166.

CaIRns, J. \& DAVERn, C. I. (I966). Effect of ${ }^{32} \mathrm{P}$ decay upon DNA synthesis by a radiation-sensitive strain of Escherichia coli. Journal of Molecular Biology 17, 418-427.

Donch, J. J., Green, M. H. L. \& Greenberg, J. (I968). Interaction of the exr and lon genes in Escherichia coli. Journal of Bacteriology 96, I704-1710.

Gray, W. J. H. \& Midgley, J. E. M. (197I). The control of ribonucleic acid synthesis in bacteria: The synthesis and stability of ribonucleic acid in rifampicin-inhibited cultures of Escherichia coli. Biochemical Journal I22, I6I-I69.

Green, M. H. L., Bridges, B. A. \& Riazuddin, S. (1971). Effect of gamma-radiation on the donor ability of $\operatorname{rec} A$ and $\operatorname{rec} A^{+\cdot}$ strains of Escherichia coli. Journal of General Microbiology 67, 63-68. 
Green, M. H. L., Gray, W. J. H., Murden, D. J. \& Bridges, B. A. (I97I). Influence of growth phase on U.V. induced lethality and DNA breakdown in a Kornberg polymerase deficient res $A$ strain of Escherichia coli. Molecular and General Genetics I12, I 10-I 16.

Howard-Flanders, P. \& Boyce, R. P. (1966). DNA repair and genetic recombination: Studies on mutants of Escherichia coli defective in these processes. Radiation Research Supplement 6, I 56-I 84.

KAPP, D. J. \& SMITH, K. C. (1970). Repair of radiation-induced damage in Escherichia coli. II. Effect of rec and $u v r$ mutations on radiosensitivity and repair of X-ray induced single strand breaks in deoxyribonucleic acid. Journal of Bacteriology ro3, 49-54.

McGrath, R. A. \& Williams, R. W. (I966). Reconstruction in vivo of irradiated Escherichia coli deoxyribonucleic acid; the rejoining of broken pieces. Nature, London 212, 534-535.

Morimyo, M., Hori, Z. I. \& SuZUKI, K. (I968). Appearance of low molecular weight DNA in a Rec ${ }^{-}$mutant of Escherichia coli K-I 2 irradiated with X-rays. Journal of Radiation Research 9, I9-25.

SмITH, K. C. (197I). The roles of genetic recombination and DNA polymerase in the repair of damaged DNA. In Photophysiology 6. Edited by A. C. Giese. New York: Academic Press.

Town, C. D., SMITH, K. C. \& KAPLAN, H. S. (I97I). DNA polymerase required for the rapid rejoining of $\mathrm{X}$-ray induced DNA strand breaks in vivo. Science, New York 172, 85I-853.

Wehrli, W., KNusel, F., Schmid, K. \& Staehelin, M. (I968). Interaction of rifamycin with bacterial RNA polymerase. Proceedings of the National Academy of Sciences of the United States of America 6r, 667-673.

Willets, N. S. \& Clark, A. J. (1969). Characteristics of some multiple recombination-deficient strains of Escherichia coli. Journal of Bacteriology roo, 23 I-239. 